\title{
Civic and Regional Engagement and Accountability
}

\section{CHEPS WORKING PAPER 04/2017}

Paul Benneworth. CHEPS (University of Twente)

\author{
p.benneworth@utwente.nl
}

This is the pre-submission version of the following chapter:

Benneworth, P. S. (2018) "Civic \& regional engagement \& accountability" in E. Hazelkorn, Coates, H. \& McCormick, A. (eds) Research Handbook on Quality, Performance and Accountability in Higher Education, Cheltenham: Edward Elgar (forthcoming).

\section{Series Editor Contact:}

Nadine Zeeman, Katharina Lemmens-Krug \& Paul Benneworth

Centre for Higher Education Policy Studies

University of Twente

P.O. Box 217

7500 AE Enschede

The Netherlands

T $\quad+3153-4893263$

F $\quad+3153-4340392$

E n.zeeman@utwente.nl

W www.utwente.nl/cheps 


\section{Table of Contents}

Abstract 3

1. Introduction: the accountability conundrum of universities' societal missions 4

2. University \& contemporary civic/ regional missions ....................................................... 6

3. Key dimensions of university contributions to civic and regional development ........................ 8

4. Quantitative measurement approaches to civic and regional engagement........................... 11

5. Qualitative evaluation approaches to university civic and regional engagement .....................14

6. Civic and Regional Engagement \& Accountability ................................................ 16

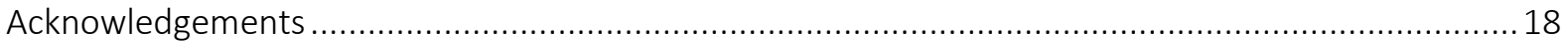

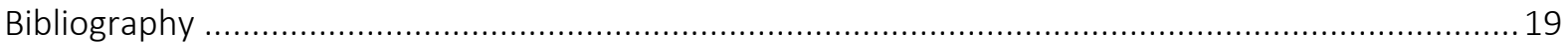




\begin{abstract}
There is an awareness that the civic mission is important for universities and higher education in general, and there is also a growing interest for the specifics on the regional engagement mission. University regional engagement involves complex webs of interactions within loosely-coupled knowledge communities that consistently defy simplistic enumeration and measurement. Under circumstances where what can be measured and strategically managed comes to become what matters for the university, then the quotidian reality of the university is that civic and regional engagement missions are not taken seriously either by university staff or management. It is this conundrum that this chapter addresses.
\end{abstract}

Key words: third mission, university accountability, performance indicators, quality assurance, university engagement, university regional engagement 


\section{Introduction: the accountability conundrum of universities' societal missions}

There is currently some confusion about the societal role of universities with the emergence of a widespread idea that universities have an innate natural tendency to become ivory towers if left to their own devices (Shapin, 2012). In the longer-term perspective there is a realisation that universities have always been intimately connected with their host societies, being as they are always dependent on those host societies for sponsorship and support (Biggar, 2010). Bender (1988) traces out how this has acquired an intimately urban character, with universities shaping the cultures and appearances of the places that host them. Felderman \& Desrochers (2003) demonstrate compellingly how the forces within a university to engage externally are so great that even as when the Johns Hopkins University forbade its academics from engaging externally that the university still fundamentally shaped the emergence of an entirely new industrial sector, technical medicine, around Baltimore in from the 1930s onwards.

Delanty (2002) argued that there have been a range of different kinds of societal mission for universities that have evolved since the medieval institution of university emerged. With the increasing complexity of society following the industrial revolution, universities acquired a range of new societal demands and expectations to support societal development. Arguably the most widely-referred of these is the way that the research mission became intertwined in the idea of the university with the emergence of the Humboldt university and the associated Humboldtian ideal (McClelland, 1998). Economic development missions became more explicit in universities with the creation of Land Grant Universities in America from 1866 onwards with their explicit mission for "extension", namely using their technical knowledge for abstract application initially conceived to be around the fields of agriculture and mechanical engineering (Kellogg, 1999). And it is this third mission (Laredo, 2007), rooted in ideas of extension, that has taken hold in the popular policy imagination when seeking to understand how universities benefit society, through creating new technologies, measured in terms of spin-offs, patents and licenses (Benneworth, 2015).

But the 'extension' mission was not the only societal contribution made by universities the Land Grant and State Universities also embodied the notion of 'service' and 'engaged scholarship' in contributing to their places (Boyer, 1990; Saltmarsh et al, 2009). Even in 
the $17^{\text {th }}$ century, Sweden realised the value of creating a new university in Lund to generate Swedish high culture in southern provinces newly acquired from Denmark (Benneworth et al, 2009). With the growth of mass suffrage and democracy in the 19th and $20^{\text {th }}$ centuries, universities became critical institutions in creating firstly new kinds of elite but then creating a highly educated mass public (Daalder \& Shils, 1982). This was first recognised in international higher education policy discourse in 1982 with the publication by the OECD CERI think-tank of the report The university and the community. The report sets out a first typology for university societal missions (see section 2 below) and made a high-level distinction between business benefits and community benefits. However, since then, there has been an explosion in awareness of and enthusiasm for the business contributions made by universities, at the same time as a neglect of these noncommercial dimensions of universities' wider missions and societal contributions. And this has become a substantial problem for universities with the rise of the new public management and strategic modernisation paradigms in higher education (Kickert, 1995; Middleton, 2003). We here use the idea of strategic management as a shorthand to encompass the three elements of this handbook, quality, performance management and accountability. Without an understanding of the strategic significance of civic and regional engagement, achieving any of these three goals becomes impossible for those activities. We characterise this as the idea of a "strategic blank" around civic and regional engagement, alluding to Benneworth's (2013) experience in interviewing a university senior manager:

"In visiting one institution to talk about their community engagement activities, a senior manager proudly showed me their institutional strategy, nine priority areas each with a detailed table giving their own aims, sub-priorities, targets and performance indicators. When turning to the page dealing with 'community engagement' (one of their own nine priority areas), unlike the other eight, except for the heading 'Community engagement', the page was completely blank' (p. 13).

There is an awareness that the civic mission is important for universities and higher education in general. But under circumstances where what can be measured and strategically managed comes to become what matters for the university, then the quotidian reality of the university is that civic and regional engagement missions are not 
taken seriously either by university staff or management. It is this conundrum that this working paper addresses.

\section{University \& contemporary civic/ regional missions}

This working paper is specifically concerned with the non-economic contributions that universities make to their places. The perennial nature of this problem is demonstrated by the fact that there have been since the original CERI report a plethora of attempts to somehow measure and better articulate universities' wider civic and regional missions. This working papers specifically asks how can civic and regional engagement be defined in order to render it suitable for strategic management, and thereby to assist with improving the quality of its delivery, managing its performance, and ultimately holding universities to account for that performance. This working paper provides a first overview of these various attempts, both underscoring the fact that there are no ideal measures for these mission activities, and secondly to demonstrate that qualitative methods are the only way to properly understand these processes. The working paper firstly sets out a more systematic definition of the university civic mission, and then presents a series of policy attempts to articulate and measure university contributions to civic and regional engagement. The working paper then concludes with a brief reflection on the boundary conditions that are necessary to effectively hold universities to account and thereby to stimulate the improvement of the contributions that they make to civic and regional development.

But to understand why this category exists (rather than just university contributions), it is first necessary to understand the way in which that non-economic contributions became excluded from the way the contribution discussions were framed. Initially, university economic contributions were conceived of as being generated through the university operating as a business, in terms of its purchasing activities, and the spending power produced by staff and students (Cooke, 1970). These views of university economic contribution persist to this day (see for example Kelly et al, 2014) but there has recently been a transformation in these roles with the perceived rise of the knowledge economy. In a knowledge economy, it is the knowledge capital that a society possesses, as much as land, labour and machinery that operates as a factor of production to drive productivity 
growth and ultimately raise living standards (Romer, 1994; Solow, 1994; Temple et al, 1998). Universities therefore can be conceptualised as providing the raw material for competitiveness and success in the knowledge economy, that knowledge capital, by embedding knowledge in students, patents, licenses and ultimately creating innovation and economic growth (Scott, 2005).

This view emerged at a time when in particular American universities were seeking a new role for themselves as engines of economic development, something that led to the passing in 1980 of the Bayh-Dole act permitting universities to benefit directly from patents granted to research based upon federal funding (Popp Berman, 2011). These strong financial interests led to the formation of a new association between leading American research universities to lobby more strongly for freedom to commercialise research results on the basis of the public value that this created, the American University Technology Managers (AUTM). The AUTM in 1987 for the first time published the result of a survey of their members that quantified this 'knowledge capital' benefit in terms of licenses, spin-offs and patents, just at the time as the Organisation for Economic Development and Co-operation, a multi-lateral economic development think-tank was starting to take the issue of innovation and technology policy seriously (Olmos-Penuela et al, 2015). These AUTM indicators have ever since cast a very long shadow over the way that university societal contribution is portrayed, with a number of countries outside America enthusiastically adopting these metrics as demonstrating university impact (e.g. HEFCE, 2001; ARC, 2002; AUCC, 2005).

There is a long-standing understanding that universities are about far more than just directly contributing the economic growth, and the pernicious effect that this view can have on the overall benefit that universities bring (Thomson, 1970; Bozeman, 2013). The effect has therefore been to occlude the view taken of non-economic contributions; because it has not been possible to develop effective metrics for them, it has proven exceptionally tricky for them to be taken seriously in policy processes (AWT, 2007). The reality has been that in attempts by universities to strategically manage their activities, civic and community engagement is all too often seen as something pending, to be dealt with in the future by developing appropriate indicators (Benneworth, 2013). And at its heart, this metric conundrum comes from the fact that the non-economic contributions of universities cover a widely disparate range of activities from a range of university 
stakeholders that produce often very small benefits for places (Vaessen \& Van der Velde, 2003). In their totality - reflecting the sheer scale of university activities - these very small activities nevertheless add up to represent substantial commitments to the places in which they are located. And this creates a substantial challenge for quality, performance and accountability in the civic mission, in trying to create a link between the strategic objectives of a university which will necessarily be limited in number, and the regional and civic contributions which may come through a range of university activities, teaching, research, service, governance, volunteering, and the physical environment.

\section{Key dimensions of university contributions to civic and regional}

\section{development}

A good understanding of the breadth of activities by which universities can contribute to communities in non-economic ways is provided by the original CERI report (1982), which offers a five-fold classification of the kinds of ways in which universities can contribute to civic and regional engagement. This is shown in Figure 1 below, highlighting the diversity between the roles the university plays, whether as a site for community knowledge creation, as a provider of knowledge for the community or insights into the community, and potentially as a means to develop solutions for community problems.

\section{Figure 1 Modes of interaction between universities and community engagement}

\begin{tabular}{|c|c|}
\hline Mode of interaction & Practical examples of university-community engagement \\
\hline University puts facilities a & Use of equipment, premises, laboratories, laboratories \\
\hline the disposal of the & Use of teachers and students to make direct contribution \\
\hline & Drawing on the community in delivering occupational training \\
\hline iversity executes order & Offering training as occupational, continuing education or cultural \\
\hline ced by community & University receives a payment from community for delivery of a service \\
\hline & A near private contract between the buyer and the vendor \\
\hline University involved in & The university comes into the community as an outside expert \\
\hline $\begin{array}{l}\text { analysis of community } \\
\text { needs }\end{array}$ & $\begin{array}{l}\text { The university provides services for the community with some reference to an 'order' by } \\
\text { the community }\end{array}$ \\
\hline University analyses & University engages at community request in developing solutions \\
\hline $\begin{array}{l}\text { problems at request of } \\
\text { community }\end{array}$ & $\begin{array}{l}\text { University has the autonomy and freedom to suggest a range of solutions away from } \\
\text { overarching pressure. }\end{array}$ \\
\hline $\begin{array}{l}\text { University delivers a } \\
\text { solution on behalf of the } \\
\text { community }\end{array}$ & $\begin{array}{l}\text { The university delivers a service for the community which is compatible with its } \\
\text { institutional status }\end{array}$ \\
\hline
\end{tabular}


Source: CERI (1982) - authors' own tabulation in Benneworth, (2013).

At the time of the CERI report, university community engagement was relatively unselfconscious, and since then as universities have sought to more actively manage community engagement a number of other kinds of intervention have occurred. Gunasekara (2006) regards the kinds of contributions captured by the CERI report as being 'generative', that is to say that there are ongoing development processes in a city or region, and the university supports them by contributing to those processes. But at the same time it is equally possible for universities to qualitatively improve the way that processes operate in a particular region, extending the scope of the regional development trajectory, what Gunasekara calls developmental contributions. These developmental contributions create new potential development pathways for places, and contribute to support the positive evolution of places (Vallance, 2016). There are at least three classes of developmental contributions that universities make to places that also need consideration in attempting to strategically manage university place contribution.

The first is the strength of what Clark (1998) called the University Steering Core, the managers within universities that develop the formal structure and informal arrangements by which universities co-ordinate their activities towards strategic goals. It was arguably Goddard \& Chatterton (1999) who first systematically pointed out that strategic regional engagement by universities resulted in universities creating substantive engagement apparatuses. These university-regional interaction interfaces were not only beneficial for the university in allowing them to manage the university, but they also contributed to the place-management of the regions in which they were located. By contributing to what Gunasekara (2006) called 'associative governance', they could help to upgrade the quality of regional-decision-making as a whole, and thereby help to facilitate wider sets of regional development processes. Indeed, universities have been latterly recognised as key actors that can contribute to regional leadership teams and deliver place-base leadership to help transform the potential and performance of cities and regions (Benneworth et al, 2017).

The second is the increasing involvement of universities in place transformation and regeneration projects, and the need to capture that in an overall mission. From the 1960s onwards, placing universities in designated locations has been regarded as an explicit tool of public place policy management, whether in ensuring that the interior of Norway 
or Australia remains populated (Rutten et al, 2003), to stimulate regeneration in old industrial regions in the Netherlands, UK and Germany (Benneworth, 2014), or encouraging the creation of branch-campuses and remote provision to provide human capital for regional development in remote rural areas (Charles, 2017). From the 1990s, an increasing involvement of universities in regeneration projects became evident, notably in the UK with the development of several new campuses by urban development corporations as part of wider programmes of large scale land remediation and redevelopment. The 2000s saw the rise of a vogue for science cities, related to an increasing appreciation of the potentials for coupling universities to knowledge-based urban development (Yigitcanlar, 2010). In the 2010s, there is a contemporary fad for smart cities in which universities, government, communities and business work together to create urban knowledge architectures that facilitate smart, social and sustainable development (Cariagliu et al, 2011; Batty, 2013).

A third addition has come through the emergence of systematic approaches to capturing the extent of university engagement. This approach took forward the spirit of the original CERI methodology in attempting to portray the variation and balance of engagement activities without necessarily attempting to quantify it (Jongbloed \& Benneworth, 2013). One of the first efforts in this regard was an attempt in the UK by the university sector association (then CVCP, later Universities UK, Goddard et al, 1993) to set out the range of dimensions across which universities contributed to their communities. This formed the basis for later efforts by the Higher Education Funding Council for England to map the regional missions of universities in England in 2001 (Charles \& Benneworth, 2001). This approach was then taken forward by the OECD in their Institutional management of higher education programme, leading to the publication Higher Education and Regions: Globally Competitive, Locally Engaged (2007). Common across all of these reports was that they distinguished a number of dimensions along which universities contributed, including but not limited to the economic dimension. All three included social, cultural and environmental dimensions, highlighting the ways that universities gave societies particular intellectual tools to deal with intractable societal problems.

In summary, civic and regional engagement by universities has both generative as well as developmental elements. Generative elements involve various kinds of university knowledge spilling out of the university and into society (and not necessarily in a linear 
manner but bound up with society's own knowledge processes). These development contributions come in helping build new regional capacities, whether that is regional strategic and leadership capacities, building new and more knowledge-intensive spaces and places, and fulfilling a kind of strategic anchor role for these places. At the same time, there is a degree of feedback and interaction between these various elements, with the opportunities for developmental change being built on prior generative outputs - policymakers become convinced of science cities because they see a potential demonstrated for example by students undertaking projects with local community groups, science cafes and lecture series, and the presence of incubators with university spin-off firms. It is precisely this dynamic, where the quantitative of the generative becomes the qualitative of the developmental that makes university civic and regional missions so difficult to address in a strategic context.

\section{Quantitative measurement approaches to civic and regional engagement}

It has proven extremely difficult to develop meaningful measures for civic and regional engagement, even within the overall development of measures for third mission activity. It is noteworthy for example that governments in both the Netherlands and Sweden committed to introducing an element of funding dependent on civic engagement activity. In both countries, the commitment was made on the assumption that it would be possible to develop measures for civic and regional engagement that were regarded as being legitimate by universities, their key stakeholders and also by policy-makers. In both cases, efforts were made to develop these indicators, but in the course of these processes it became evident that the measures that were most readily available commanded relatively little respect, and could even lead to perverse behaviours (such as measures of press activity rewarding universities who were embroiled in conflicts with their localities).

Arguably the most successful attempt to develop meaningful measures for the civic and regional mission for universities has been the UK's Higher Education, Business and Community Interaction Survey (HEBCIS). Although the survey carried the title of Higher Education Business Interaction (HEBI) survey when it was created (Charles \& Conway, 
2002), the title was quickly changed to reflect the realisation that the measures of community interaction were as important to universities as the commercial measures. The structure of the questionnaire used to gather the data collected data on strategy, infrastructure, intellectual property, but also regeneration, continuing professional development and social and cultural contributions. The questionnaire included a mix of categorical answers but also hard data, and in the hard data gathering area, whilst there were 12 kinds of data gathered for knowledge exchange indicators, there were two indicators gathered for social and cultural engagement, namely attendance and free and paid for events at the universities.

In policy practice, however, it became clear that whilst the IP indicators commanded sufficient legitimacy to be used as the basis for further interventions, the social and community indicators did not. Within the UK, since 2003, the Higher Education Innovation Fund allocated funding to universities for their third mission activities based on their performance against a limited number of their commercialisation indicators. Although there were attempts made in the mid-2000s to leave some funding free from indicators to encourage other activity, this was dropped in 2007, giving universities strong incentives to encourage commercialisation rather than other kinds of engagement. The current England methodology involves allocating universities funding for innovation support based on qualifying income (largely commercialisation activity with SMEs in the last three years) and having in place a suitable knowledge exchange strategy. Community and societal engagement is also missing from the headline messages HEFCE presents about its knowledge exchange activities, with the Key Indicators relating almost exclusively to collaborative/ contract research commercialisation and IP (http://www.hefce.ac.uk/kess/hebci/indicators/)

There have been a number of attempts to develop other summary measures of regional and civic engagement as parts of various kinds of transparency exercises, although none have been able to satisfactorily develop a meaningful indicator. Regional and community engagement indicators are absent from the majority of league tables, whether national or international in their scope. The leading ranking model to use some kind of regional indicators is the European Commission's Multirank model. The 2015 rankings had five measures for regional engagement, including graduate retention, student internships, joint publication and commercial income relating to the region. Although these five 
indicators relate in some way to the regional mission of universities, it is not clear that these five indicators provide the best coverage of the ways in which universities contribute to their host regions. In particular, graduate student retention is strongly dependent on graduate opportunities within the host region as much as for the suitability of the graduates being produced for the employment opportunities.

A similar story emerges with a more recent attempt by the European Commission to measure the societal contribution of universities, through the Eunivation project. The project undertook a comprehensive literature review and identified the various kinds of dimensions that had to be captured to satisfactorily measure universities' social and civic contributions. On that basis, a number of potential indicators for engagement were proposed that could potentially measure civic and regional engagement (see below).

\section{Figure 2 Indicators used in scientific literature to measure}

\begin{tabular}{|l|l|}
\hline Media engagement & $\begin{array}{l}\text { Number of media appearances by staff } \\
\text { Social media mentions, cites, appearances }\end{array}$ \\
\hline Societal engagement/ & third mission objectives included in HE policy or strategies \\
education & Specific internal budgetary allocations to third mission activities \\
& Numbers of academics engaged/volunteering for third mission activities \\
(Numbers of) Events/facilities open to third mission activities & Numbers of research initiatives with direct impact on community \\
& Staff student resources (time/cost) allocated to delivery of community services and facilities \\
& Attendance figures for facilities/events \\
\hline Educational outreach & Staff/student numbers dedicated to educational outreach \\
& HEl budget allocated to educational outreach activities \\
& Numbers of community participants \\
\hline Community outreach & No of community representatives on HEI Committees/Boards \\
& Value of income from community partnership agreements, etc. \\
\hline $\begin{array}{l}\text { Interaction with third } \\
\text { mission stakeholders }\end{array}$ & HEFCE: REF impact cases (aggregate data) - potential indicator \\
\hline
\end{tabular}

Source: Eunivation final report (in press).

Three indicators were then selected as being the most relevant for further validation, media appearances by staff and students, third mission policies and budget for outreach activities. The project then proceeded to validate the extent to which these were 'good' indicators in the sense of being feasible to gather, relevant to the characteristic under consideration and to which stakeholders regarded them as legitimate measures of the particular dimension. In that validation process, none of these indicators emerged as a sensible measure for university contributions to innovation. Taken together with the HEFCE, Netherlands and Norwegian examples of failure to develop meaningful engagement measures (and indeed the Benneworth (20130) anecdote), this suggests that 
there is no realistic prospect of developing meaningful indicator-based transparency tools for quality, performance and accountability purposes.

\section{Qualitative evaluation approaches to university civic and regional engagement}

An alternative approach is the use of qualitative approaches to civic engagement by universities, in particular using an objective external standard against which universities either self-evaluate or are peer-reviewed for their compliance or otherwise (Benneworth, 2010). A benchmarking approach identifies which processes are salient for the delivery of a particular outcome, in this case civic and regional engagement, and identifies difference performance levels for each process between broadly speaking strong, average and weak performers. By understanding how an institution performs each process, this provides strong information for improving internal performance, and used expertly it can act to drive internal change. However, the use of benchmarking as a tool for accountability is limited by the fact that although universities compare themselves against a group, it is meaningless to create league tables or rankings on the basis of performance.

One of the first approaches in this area was the development by HEFCE (in England) in 2002 of a benchmarking tool for regional engagement (Charles \& Benneworth, 2002). This tool was developed in parallel with a series of regional profiles of university engagement, and was intended to help universities with improving their own internal processes. The tool involved universities firstly assessing their own regional engagement in a series of areas, then extending it to a review by external partners and potentially peers from outside the region (Charles et al, 2010). Originally, the issue of civic and community engagement was only dealt with relatively weakly, but the tool was revised in response to a request from a university engagement association, PASCAL. The final version of the tool benchmarked universities against seven processes, namely enhancing regional infrastructure, human capital development, business development, social capital development, community development, cultural development and sustainability.

A second evaluation approach is the Carnegie Classification for Community Engagement, which created as an elective classification within the wider tool (Ward et al, 2013). As 
Ward et al (2013) note, what was originally a classification for higher education researchers evolved into a typology of the kinds of universities that affected those institutions' identity. As with typologies involving vertical segmentation led to behavioural effects that were not necessarily intended by the Classification developers at the outset. The Classification saw this tendency to use it as a ranking as undesirable and therefore developed elective classification elements into which HEIs could opt, thereby undermining the idea of a single vertical classification. The Carnegie Classification for Community Engagement benchmarked institutions against five dimensions, namely vision \& leadership, infrastructure, infrastructure, assessment opportunities, and policies. In 2015240 universities were awarded the Classification, and from 2017 responsibility for the administration of the Classification passed to the Swearer Centre for Public Engagement at Brown University. More detail on the classification can be found via this link.

A final example of qualitative methodologies for measuring civic and regional engagement by universities is given by the HEI Innovate tool, HEI Innovate, jointly developed between the OECD and the European Commission. It adopts again a version of the benchmarking process combined with a very strong emphasis on both internal dialogue and external peer learning to create a momentum for change. The tool explores seven dimensions of the ways in which universities contribute to innovation: although the emphasis is not specifically on civic and regional impact (and there is indeed an element around internationalisation), there is a very strong and clear overlap with and interest in HEI Innovate in universities which are concerned with strategically managing their regional engagement mission.

1. Leadership and Governance

2. Organisational Capacity: Funding, People and Incentives

3. Entrepreneurial Teaching and Learning

4. Preparing and Supporting Entrepreneurs

5. Knowledge Exchange and Collaboration

6. The Internationalised Institution

7. Measuring the impact

HEI Innovate (u.d., p.1) 
The tool is optional in that institutions can pursue one or more of the dimensions that are of specific interest for them. HEI Innovate uses a website for invited users to rapidly collate data and provide visualisations, to increase the numbers of stakeholders (internal and external) that are able to provide input into the benchmarking exercise. More significantly as the number of registered users increases (744 at the time of writing), it is also possible to provide data visualisations of the chosen institutions against the global mean or against a group of comparable institutions.

\section{Civic and Regional Engagement \& Accountability}

This working paper has been concerned with the puzzling question of how universities can deal with issues of quality, performance and accountability in civic and regional engagement. The problem arises that the reality is that for the majority of universities, that this will never be the most important strategic mission. Rather most universities have some version of an intention to ensure that synergies emerge from other core missions to contribute effectively to their host cities and regions. And it is this particular characteristic of civic and regional engagement that makes it very hard to use a standard transparency approach of measure, manage and monitor to deal with the challenge. Indeed, in this working paper we have seen (a) that attempts to produce rigorous measures of impact for funding purpose have failed, (b) broader attempts to develop quantitative measures have floundered on the diversity of activities involved, and (c) qualitative measures are strongly dependent on universities self-reported behaviour to provide serious leverage to hold universities account.

There is a problem with regional and civic engagement missions that they are only selectively relevant, as the Carnegie Classification makes explicit. And although many universities have considerable regional impacts (even those that do not see it as being strategically important), the question remains as to how - in the absence of compelling accountability measures - can interest be stimulated within university strategic managers. For those that seem interested in developing their regional engagement activities, there are a range of tools and support networks (including Carnegie and HEI Innovate) that can help the universities to develop those strategic goals. But for those that suffer from a strategically blank centre despite a strongly engaged hinterland, there 
are clearly problems in being convinced that a regional and civic mission can augment, rather than undermine, strategic capacities. All too often, the absence of metrics for engagement is seen as confirming the message that relevance comes at the expense of rigour, that engagement can only be delivered by sacrificing excellence.

And that is the great challenge for accountability, performance and quality in regional and civic engagement, that vertical segmentation in the way that the activity is perceived by university senior managers. Addressing that vertical segmentation is made more difficult because elite universities have considerable autonomy, but their elite status allows them to determine what constitutes excellence for the sector as a whole, the very strong endogeneity property of excellence in higher education. Nevertheless, it is clear that engagement by HEIs is important to societal development as much in the 21st century as it ever was, but that it is operating because of this regulatory failure outside a legitimate transparency framework. It is this issue of legitimacy in transparency arrangements that is necessary if policy-makers are to effectively steer universities to manage their activities to realise the considerable potential they have to drive economic and social development in the 21st century. 


\section{Acknowledgements}

The author would like to acknowledge the inputs of David Charles, Elaine Ward and Andrea Hofer in the material that appears in the qualitative benchmarking section. 


\section{Bibliography}

ARC (2002) National survey of research commercialisation, Canberra: Australian Research Council.

AUCC (2005) Momentum: The 2005 report on university research and knowledge transfer, Ottowa: Association of Universities and Colleges of Canada

Adviesraad voor Wetenschaps- en Technologiebeleid (2007), Alfa en Gamma stralen. Valorisatiebeleid voor de Alfa- en Gammawetenschappen, Rijswijk: AWT

Batty, M. (2013). Big data, smart cities and city planning. Dialogues in Human Geography, 3(3), 274-279.

Benneworth, P. (2010) A Handbook of university benchmarking, Brussels: the European Centre for the Strategic Management of Universities.

Benneworth, P. (2013) "University Engagement with Socially Excluded Communities"; in P. Benneworth (ed.) University engagement with socially excluded communities, Dordrecht, Springer.

Benneworth, P. (2014) “Decoding university ideals by reading campuses" in P. Temple (ed.) The physical university, London: Routledge.

Benneworth, P. (2015) "Tracing how arts and humanities research translates, circulates and consolidates in society.. How have scholars been reacting to diverse impact and public value agendas?" Arts and Humanities in Higher Education Vol 14, Issue 1, pp. 45 - 60 doi:10.1177/1474022214533888

Benneworth, P. S., Coenen, L., Moodyson, J. \& Asheim, B. (2009) “Exploring the multiple roles of Lund University in strengthening the scania regional innovation system: towards institutional learning? European Planning Studies 17:11, 1645 - 1664

Bender, T. (1988) 'Introduction', pp. 3-10 in: T. Bender (ed.), The University and the City. From Medieval Origins to the Present. New York/Oxford: Oxford University Press.

Benneworth, P. S. Pinheiro, R. \& Karlsen, J. (2017) “Strategic Agency and Institutional Change: Investigating the Role of Universities in Regional Innovation Systems (RISs)" Regional Studies 51 (2) pp. 235-248 doi: 10.1080/00343404.2016.1215599.

Biggar, N. (2010) “What are universities for” Standpoint 24, pp. 76-79.

Boyer, E. L. (1990) Scholarship Reconsidered: Priorities of the Professoriate, Carnegie Foundation for the Advancement of Teaching and Jossey-Bass, New York.Delanty, G. (2002) 'The university and modernity: a history of the present', in Robins, K. and Webster, F. The Virtual University: Knowledge, Markets and Management, OUP, Oxford.

Caragliu, A., Del Bo, C., \& Nijkamp, P. (2011). Smart cities in Europe. Journal of urban technology, 18(2), 65-82.

Charles, D. (2017). The rural university campus and support for rural innovation. Science and Public Policy. 
Charles, D. and Benneworth , P (2001) The Regional Mission: The Regional Contribution of Higher Education: National Report, Universities UK/HEFCE, London

Charles, D. R., Benneworth, P., Conway, C. \& Humphrey, L. (2010) 'How to benchmark university-community interactions' in Inman, P. \& Schütze, H. G. (eds) The Community Engagement and Service Mission of Universities, Leicester (UK): NIACE.

Charles, D. R. \& Benneworth, P. (2002) Evaluating the Regional Contribution of an HEI: A Benchmarking Approach, Bristol, HEFCE

Charles, D.R. and Conway, C. (2002) Higher Education Business Interaction Survey. HEFCE, Bristol.

Clark B. R. (1998) Creating entrepreneurial universities: organizational pathways of transformation. Pergamon, New York.

Goddard, J, Charles, DR, Pike, A, Potts, G and Bradley, D. (1994) Universities and Their Communities, London: Committee of Vice Chancellors and Principals.

Cooke, E. D. (1970) "Analyzing university student contribution to the economic base of the community" Annals of Regional Science 4 (1) pp 146-153

Daalder, H. \& Shils, E. (1982) Universities, politicians and bureaucrats: Europe and the United States, Cambridge, Cambridge University Press.

Feldman M. \& Desrochers, P. (2003) Research Universities and Local Economic Development: Lessons from the History of the Johns Hopkins University, Industry \& Innovation 10, 5-24.

Goddard, J,B. and Chatterton, P. (1999) The Response of Higher Education Institutions to Regional Needs, OECD, Paris

HEFCE (2001) "Higher education-business interaction survey”, HEFCE Research Report 01/68, London: HEFCE

HEI Innovate (u.d.) Background note on HEI Innovate, Paris: OECD.

Jongbloed, B. \& Benneworth, P. (2013) “Learning from History: Previous Attempts to Measure Universities' Community Impacts" in P. Benneworth (ed.) University engagement with socially excluded communities, Dordrecht, Springer.

Kellogg Commission on the Future of State and Land-Grant Universities (1999) Returning to our Roots: The Engaged University, Third report, National Association of State Universities and Land-Grant Colleges, Washington DC.

Kelly, U., McNicoll, I. \& White, J., (2014)' The economic impact of universities in the UK' London: Universities UK.

Kickert, W. (1995), Steering at a Distance: A New Paradigm of Public Governance in Dutch Higher Education. Governance, 8: 135-157

Larédo, P. (2007) "Revisiting the Third Mission of Universities: Toward a Renewed Categorization of University Activities?" Higher Education Policy (2007) 20, pp. 441-456 
McClelland, C. E. (1988) “'To Live for Science': Ideals and Realities at the University of Berlin”, pp. 181-197 in: T. Bender (ed.), The University and the City. From Medieval Origins to the Present. New York/Oxford: Oxford University Press

Middleton, Chris. "Models of state and market in the'modernisation'of higher education." British Journal of Sociology of Education 21.4 (2000): 537-554.

OECD (2007) Higher Education and Regions: Globally Competitive, Locally Engaged, Paris: OECD.

Romer, P. M. (1994) “The origins of endogenous growth" Journal of Economic Perspectives 8 (1) pp 322 .

Rutten, R. Boekema, F. \& Kuypers, E. (2003a) "HEIs, regions and the knowledge-based economy" in R. Rutten, F. Boekema, \& E. Kuypers, (eds) Economic Geography of Higher Education: Knowledge, Infrastructure and Learning Regions, London: Routledge

Saltmarsh, J., Giles, D. E., Ward, E., \& Buglione, S. M. (2009). Rewarding community-engaged scholarship. New directions for higher education, 2009(147), 25-35.

Sarimin, M. and Yigitcanlar, T. (2012). "Towards a comprehensive and integrated knowledgebased urban development model: Status quo and directions". International Journal of Knowledge-Based Development, 3 (2), 175-192.

Scott, P. (2005). Universities and the knowledge economy. Minerva, 43(3), 297-309.

Schuetze, H. G. (2012). Universities and their communities-Engagement and service as primary mission. In Higher Education and Civic Engagement (pp. 61-77). Palgrave Macmillan US.

Shapin, S (2012) The Ivory Tower: the history of a figure of speech and its cultural uses. British Journal for the History of Science, 45(1): 1-27.

Solow, R. (1994) "Perspectives on growth theory" Journal of Economic Perspectives 8 (1) pp 45 54.

Temple, J. (1998) “The new growth evidence” Journal of Economic Literature, 37 (1) pp. 112156

Thompson, E P (1970) Warwick University Ltd. Penguin, London.

Vaessen, P. and Velde, M. van der (2003), University knowledge transfer through social and professional embeddedness: a case study, in Boekema, F. Kuypers, E., Rutten, R. (eds.), Economic Geography of Higher Education: Knowledge, Infrastructure and Learning Regions London: Routledge.

Vallance, P. (2016). Universities, Public Research, and Evolutionary Economic Geography. Economic Geography, 92(4), 355-377.

Ward, E., Buglione, S., Giles, D. E \& Saltmarsh, J. (2013) “Helping Create the "New Normal” in American Higher Education?" in P. Benneworth (ed.) University engagement with socially excluded communities, Dordrecht, Springer. 
Yigitcanlar, T. (2010). "Making Space and Place for the Knowledge Economy: Knowledge-based Development of Australian Cities." European Planning Studies, 18(11), 1769-1786.) 
The Center for Higher Education Policy Studies (CHEPS) is a research institute (WHW, Article 9.20) located in the Faculty of Behavioural and Management Sciences within the University of Twente, a public university established by the Dutch government in 1961. CHEPS is a specialized higher education policy centre that combines basic and applied research with education, training and consultancy activities.

Center for

Higher Education

Policy Studies 